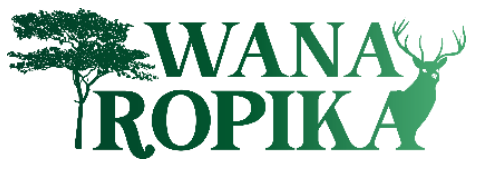

Journal Wanatropika. Vol. 11, No. 2 November 2021

Journal home page: https://jurnal.instiperjogja.ac.id/index.php/JWT/

ISSN: 2088-7019

\title{
SERAPAN KARBON PADA SISTEM AGROFORESTRY BERBASIS GAHARU (Gyrinops versteegii) DI SRAGEN DAN KARANGANYAR, JAWA TENGAH
}

\section{Carbon Sequestration at Several Gaharu-Based Agroforestry Practices in Sragen and Karanganyar, Central Java}

\author{
Rawana $^{1}$, Suryo Hardiwinoto' ${ }^{2}$ Budiadi $^{2}$, Sri Rahayu' \\ ${ }^{1}$ Fakultas Kehutanan Institut Pertanian Stiper Yogyakarta, \\ ${ }^{2}$ Fakultas Kehutanan Universitas Gadjah Mada Yogyakarta \\ Korespondensi Penulis: wanatropikajurnal@gmail.com
}

\begin{abstract}
Agroforestry, the practice of growing trees and crops in interacting combinations, has a pivotal role to reduce the $\mathrm{CO}_{2}$ concentration in the atmosphere, and it subsequently sequesters the carbon in part of stems, branches, roots, and crowns of the trees composing their vegetation communities. The objective of the research is to know the carbon sequestration in the three agroforestry practices; those are multilayer tree garden, taungya, and home garden. The research was carried out from April 2017 to March 2018 at Sragen and Karanganyar regency central Java Province. Plot method, with the plot size of $20 \mathrm{~m} \times 20 \mathrm{~m}$ for trees, $10 \mathrm{~m} \times 10 \mathrm{~m}$ for pole, and $5 \mathrm{~m} \times 5 \mathrm{~m}$ for sapling, was used in the sampling. The carbon sequestration was measured by Chave's allometric equation. The carbon sequestration of above ground the trees

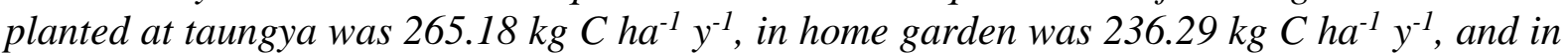
multi layer tree garden was $290.14 \mathrm{~kg} \mathrm{C} \mathrm{ha-1}^{-1}$. Seasonal fluctuation of the higest carbon sequestration in home garden occurs on October-December; in multilayer tree garden occurs on January-March; and in taungya occurs on July-September.
\end{abstract}

Key words: Agroforestry practices, G.versteegii, seasonal fluctuation, Carbon sequestration

\section{PENDAHULUAN}

Meningkatnya konsentrasi gas rumah kaca (greenhouse gases $/ G H G$ ) terutama gas $\mathrm{CO}_{2}$ merupakan penyebab utama terjadinya pemanasan global (global warming), suhu meningkat mencapai 1,5 - 4,5 ${ }^{\circ} \mathrm{C}$ (Peichl et al., 2006; Agonafer dan Worku, 2017). Peningkatan konsentrasi $\mathrm{CO}_{2}$ di atmosfer mempunyai dampak positif terhadap peningkatan produktivitas tanaman, tetapi mempunyai dampak negatif yang lebih besar yaitu perubahan iklim, peningkatan suhu 
udara, tingginya intensitas kekeringan dan banjir. Di samping itu konversi lahan hutan menjadi lahan pertanian berdampak pada peningkatan suhu tanah, dan penurunan kelembapan udara pada zona perakaran (Saha dan Pramod, 2012).

Praktik penggunaan lahan seperti aforestasi, reforestasi, permudaan alami hutan, sistem silvikultur, dan agroforestry dapat mengurangi konsentrasi kandungan $\mathrm{CO}_{2}$ di atmosfer (SotoPinto et al.,2010). Tipe penggunaan lahan yang berbeda mempunyai peran yang berbeda dalam pengurangan konsentrasi $\mathrm{CO}_{2}$ di atmosphere dan tingkat emisi gas rumah kaca (Soto-Pinto et al., 2010). Sistem agroforestry (termasuk agrisilvikultur) sangat dipertimbangkan sebagai penyerap dan penyimpan karbon ( $C$ sink) dikarenakan pengintegrasian dengan pohon-pohon yang dapat menyerap $\mathrm{CO}_{2}$ dari atmosfer kemudian menyimpannya dalam pohon secara permanen (Peichl et al., 2006). Sistem agroforestry, di samping berpotensi menyerap karbon juga dapat berkembang menjadi sebuah alternatif teknologi untuk mengurangi tingkat deforestasi pada zona tropis dan menawarkan variasi produk untuk layanan komunitas pedesaan (Soto-Pinto et al., 2010).

Serapan karbon dalam sistem agroforestry dipengaruhi oleh struktur, komposisi jenis dan fungsi masing-masing komponen dalam sistem agroforestry (Peichl et al., 2006; SotoPinto et al., 2010). Kapasitas agroforestry dalam menyerap karbon tergantung pada jenis, keanekaragaman (biodiversity), kondisi tanah, iklim, dan geografi (Natalia et al., 2017). Sistem agroforestry yang diterapkan di daerah tropis dapat menyerap karbon di atas tanah sebesar 0,29-15,21 Mg C ha $\mathrm{th}^{-1}$, sedangkan karbon yang diserap di bawah tanah dengan kedalaman di atas $1 \mathrm{~m}$ sebesar 10-300 $\mathrm{Mg} \mathrm{C} \mathrm{ha}^{-1} \mathrm{th}^{-1}$ (Nair et al., 2010). Adapun menurut Peichl et al., (2006) potensi serapan dan simpanan karbon pada sistem agroforestry di daerah tropis sebesar 21-240 Mg C per hektar, sedangkan serapan dan simpanan karbon di lahan agroforestry di daerah sub tropik mencapai $10-280 \mathrm{Mg}$ C per hektar.

Pohon Gyrinops versteegii didomestikasi di Pulau Jawa pada tahun 2000 (Mulyaningsih dan Yamada, 2007) dengan sistem agroforestry di lahan pekarangan, kebun, maupun di lahan persawahaan. Sistem ini berdampak pada perubahan landscape, dari ekosistem persawahan menjadi ekosistem kebun campur yang terdiri dari pepohonan dengan tajuk berstrata yang berfungsi seperti hutan. Perubahan ekosistem persawahan menjadi ekosistem agroforestry dapat meningkatkan serapan karbon dan menyimpannya di vegetasi penyusun secara permanen (vegetational storage), sehingga dapat menurunkan konsentrasi gas $\mathrm{CO}_{2}$ di atmosfer. Menurut International Panel on Climate Change (IPCC) merekomendasikan perbaikan mitigasi peningkatan emisi $\mathrm{CO}_{2}$, diantaranya adalah aforestasi, dan konversi lahan pertanian menjadi lahan agroforestry. Penelitian tentang serapan karbon pada berbagai sistem 
agroforestry masih sedikit (Peichl et al., 2006). Adapun penelitian tentang serapan karbon pada sistem agroforestry berbasis gaharu di Jawa Tengah belum dilakukan. Penelitian tentang serapan karbon pada lahan yang berasal dari konversi lahan persawahan menjadi kebun campur dan taungya juga belum dilakukan. Tujuan penelitian ini adalah (1) Untuk mengetahui potensi serapan karbon di atas tanah di lahan agroforestry berbasis gaharu, (2) Untuk mengetahui fluktuasi musiman serapan karbon di atas tanah di lahan agroforestry berbasis gaharu di Karanganyar dan Sragen, Jawa Tengah.

\section{BAHAN DAN METODE}

Penelitian ini dilakukan di Desa Bendungan, Kecamatan Kedawung, Kabupaten Sragen dan Desa Gayam Dompo, Kecamatan Karanganyar, Kabupaten Karanganyar, Jawa Tengah. Desa Bendungan secara geografis terletak pada $7^{\circ} 28^{\prime} 31.18^{\prime \prime S}-7^{\circ} 28^{\prime} 40.95^{\prime \prime}$ dan $111^{\circ} 2^{\prime} 55.55^{\prime \prime E}-$ $111^{\circ} 3$ '8.50"E, dengan ketinggian tempat $116 \mathrm{~m}$ di atas permukaan laut. Kelerengan lahan ratarata sebesar 2-3\%, dengan tipe tanah grumosol kelabu. Curah hujan rat-rata $2.123 \mathrm{~mm} / \mathrm{tahun}$ dengan jumlah hari hujan 119 (Badan Pusat Statistik/BPS ${ }_{\mathrm{a}}$, 2017). Adapun lokasi penelitian yang berada di Kabupaten Karanganyar terletak di Kelurahan Gayam Dompo, Kecamatan Karanganyar. Secara geografis Kelurahan Gayam Dompo terletak pada 7³6'55.70"S $7^{\circ} 37^{\prime} 3.71$ "S dan $111^{\circ} 00^{\prime} 40.70^{\prime \prime} \mathrm{E}-111^{\circ} 0^{\prime} 50.26$ "E, dengan ketinggian tempat $313 \mathrm{~m} \mathrm{dpl}$. Berdasarkan Schmidt dan Ferguson, Kelurahan Gayam Dompo mempunyai tipe iklim C (agak basah) dengan rata-rata bulan basah 9 bulan dan bulan kering 3 bulan. Dalam 10 tahun terakhir rata-rata curah hujan berada antara $2.094 \mathrm{~mm} /$ tahun sampai $3.424 \mathrm{~mm} / \mathrm{tahun}$, dengan jenis tanah mediteran coklat $\left(\right.$ BPS $\left._{b}, 2017\right)$. Kedua lokasi penelitian merupakan areal domestikasi pohon G.versteegii yang ditanam pada tahun 2004 dengan pola agroforestry. Berdasarkan Nair (1993) diklasifikasikan dalam sistem agrisilvikultur, dengan praktik (practice) yang berbeda yaitu kebun campur, taungya dan pekarangan.

Bahan yang digunakan dalam penelitian ini adalah tanaman G.versteegii beruumur 14 tahun. Alat yang digunakan dalam penelitian ini adalah kompas, GPS, pita meter, tali plastik dengan panjang $20 \mathrm{~m}$, galah ukur panjang $1.3 \mathrm{~m}$, tally sheet, komputer, kamera, dan haga meter.

Pengambilan sampel digunakan plot bertingkat (nested plot), ukuran $5 \mathrm{~m}$ x $5 \mathrm{~m}$ digunakan untuk pengukuran sapihan (pohon kecil dengan diameter kurang dari $10 \mathrm{~cm}$ ), plot ukuran 10 m x 10 m untuk mengukur tingkat sapihan yaitu pohon dengan diameter lebih besar atau sama dengan 10 dan kurang dari $20 \mathrm{~cm}$. Plot ukuran $20 \mathrm{~m}$ x $20 \mathrm{~m}$ untuk tingkat pohon, yaitu pohon dengan diameter lebih besar atau sama dengan $20 \mathrm{~cm}$ (Standar Nasional Indonsia, 
2011; Noor'an et al., 2015; dan Ismoto dan Farida, 2017). Parameter yang digunakan dalam penelitian ini yaitu (1) Tinggi pohon, (2) Diameter pohon (dbh) dan (3) Berat jenis kayu.

Perhitungan biomassa pohon dengan menggunakan persamaan alometrik yang dikembangkan oleh Chave et al. (2005) untuk daerah lembab dengan curah hujan antara 1800 $\mathrm{mm} /$ tahun sampai dengan $6000 \mathrm{~mm} /$ tahun sebagai berikut:

$(A G B)_{e s t}=\exp \left(-2.977+\ln \left(\rho D^{2} H\right)\right) \equiv 0.0509 \times \rho D^{2} H$

Dimana:

AGB : biomassa di atas tanah

$\rho \quad$ : berat jenis kayu $\left(\mathrm{g} / \mathrm{cm}^{3}\right)$

D : pertumbuhan diameter setinggi dada $(\mathrm{cm})$

$\mathrm{H} \quad$ : tinggi pohon (m), exp:2,718.

Fluktuasi serapan karbon dihitung dengan menggunakan persamaan rumus (1), dimana nilai $\mathrm{D}$ digantikan $\Delta \mathrm{D}$ yang merupakan pertumbuhan diameter yang diukur setiap tiga bulan. Pengukuran diawali pada awal bulan April (bulan ke-4) 2017 dan berakhir pada akhir bulan Maret (bulan ke-3) 2018. Perhitungan fluktuasi serapan karbon dihitung setiap tiga bulan, yaitu periode April-Juni, Juli-September, Oktober-Desember, dan Januari-Maret. Serapan karbon tiap pohon ditaksir dengan mengalikan biomasa pohon di atas tanah dengan faktor konversi kandungan karbon (digunakan nilai default 0,46) (Hairiah et al., 2010).

\section{HASIL DAN PEMBAHASAN}

\section{Serapan Karbon di Lahan Praktik Agroforestry}

Serapan karbon di atas tanah vegetasi penyusun di kebun campur yaitu sebesar 290,14 $\mathrm{kg} \mathrm{C} \mathrm{ha}^{-1} \mathrm{th}^{-1}$ lebih tinggi dibandingkan di lahan taungya $\left(265,18 \mathrm{~kg} \mathrm{C} \mathrm{ha}^{-1} \mathrm{th}^{-1}\right)$ dan di lahan pekarangan (236,29 $\left.\mathrm{kg} \mathrm{C} \mathrm{ha}^{-1} \mathrm{th}^{-1}\right)($ Gambar 1). Serapan karbon di atas tanah vegetasi penyusun tingkat sapihan di kebun campur yaitu sebesar 3,00 $\mathrm{kg} \mathrm{C} \mathrm{ha}^{-1} \mathrm{th}^{-1}$ lebih tinggi dibandingkan dengan di lahan taungya $\left(2,70 \mathrm{~kg} \mathrm{C} \mathrm{ha}^{-1} \mathrm{th}^{-1}\right)$ dan di pekarangan $\left(0,56 \mathrm{~kg} \mathrm{C}^{-1} \mathrm{hh}^{-1}\right)$. Serapan karbon di atas tanah vegetasi penyusun tingkat tiang di kebun campur $\left(103,65 \mathrm{~kg} \mathrm{C} \mathrm{ha}^{-1} \mathrm{th}^{-1}\right)$ lebih tinggi dibandingkan dengan di lahan pekarangan $\left(2,93 \mathrm{~kg} \mathrm{C} \mathrm{ha}^{-1} \mathrm{th}^{-1}\right)$ dan di taungya $\left(31,90 \mathrm{~kg} \mathrm{C} \mathrm{ha}^{-1} \mathrm{th}^{-1}\right)$. Selanjutnya, serapan karbon di atas tanah vegetasi penyusun tingkat pohon di lahan pekarangan $\left(232,80 \mathrm{~kg} \mathrm{C} \mathrm{ha}^{-1} \mathrm{th}^{-1}\right)$ lebih tinggi dibandingkan dengan di lahan taungya (230,58 kg C ha $\left.\mathrm{kh}^{-1}\right)$ dan di kebun campur (183,49 $\left.\mathrm{kg} \mathrm{C} \mathrm{ha-1} \mathrm{th}^{-1}\right)$ (Tabel 1). Persentase serapan karbon di atas tanah tingkat sapihan, tiang dan pohon di lahan taungya berturut-turut adalah 1,02\%,12,03\% dan 86,95\%; di lahan pekarangan masing-masing adalah 
0,24\%, 1,24\% dan 98,52\%; dan di lahan kebun campur berturut-turut adalah 1,03\%, 35,72\% dan $63,24 \%$.

Serapan karbon di tiga lokasi praktik agroforestry menunjukkan bahwa terdapat kecenderungan tingkat pohon mempunyai persentase serapan karbon lebih tinggi dibandingkan dengan tingkat tiang dan sapihan. Persentase serapan karbon tingkat pohon tertinggi pada lahan pekarangan yaitu sebesar 98,52\%, kemudian diikuti oleh taungya $(86,95 \%)$ dan kebun campur (63,24\%). Penelitian ini sesuai dengan penelitian yang dilakukan oleh Labata et al., (2012) yang menemukan bahwa persentase serapan karbon sistem mixed multistory, taungya dan Falcata-coffeee system pada tingkat pohon lebih tinggi dibandingkan dengan tingkat tiang dan sumber karbon yang lain yaitu masing-masing sebesar $94 \%, 91 \%$, dan $85 \%$.

Dibandingkan dengan penelitian yang dilakukan oleh Nair et al., (2010) terhadap praktik agroforestry fodder bank yang dilakukan di Afrika Barat terhadap tanaman Gliricidea sepium, Pterocarpus lucens dan P. erinacens, serapan karbon di atas tanah di praktik agroforestry sebesar $290 \mathrm{~kg} \mathrm{C} \mathrm{ha}^{-1} \mathrm{th}^{-1}$, hampir sama dengan serapan karbon di lahan kebun campur di Sragen. Hasil penelitian serapan karbon di lokasi penelitian lebih rendah jika dibandingkan dengan hasil penelitian Lorenz dan La1 (2010) yang menemukan serapan karbon di hutan yang tidak terganggu di hutan tua boreal di Hemisphere Utara sebesar $400 \mathrm{~kg} \mathrm{C}^{-1}$ $\mathrm{th}^{-1}$, dan di hutan tropik sebesar $490 \mathrm{~kg} \mathrm{C} \mathrm{ha}^{-1} \mathrm{th}^{-1}$.

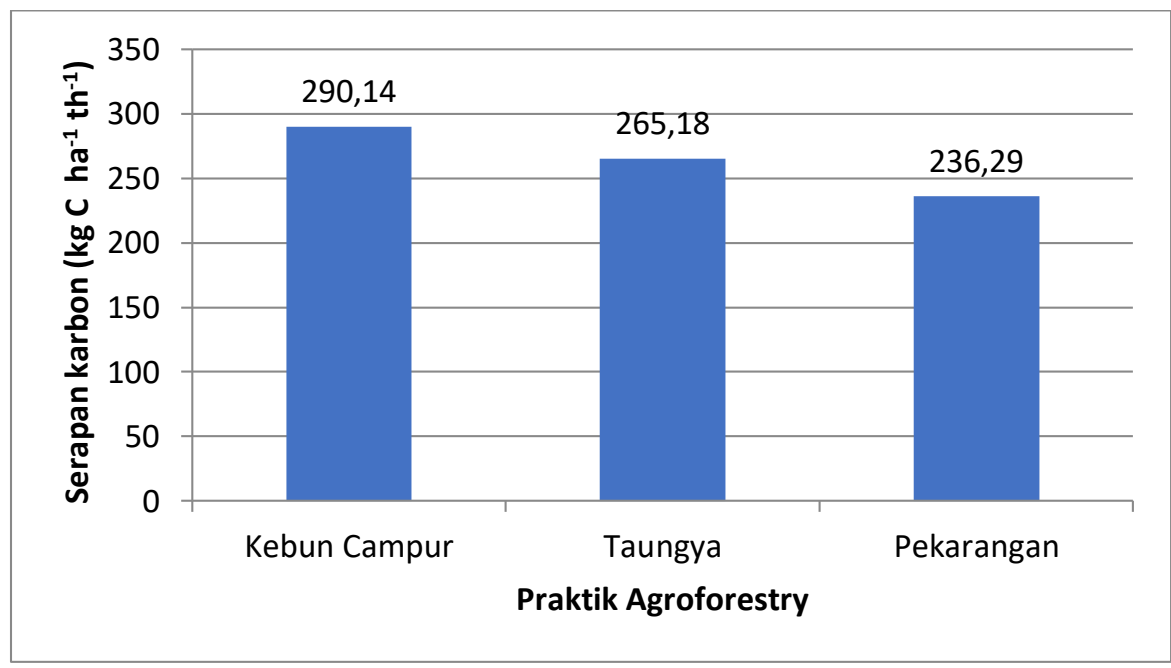

Gambar 1. Serapan karbon di atas tanah selama satu tahun di tiga praktik agroforestry 
Tabel 1. Serapan karbon musiman $\left(\mathrm{kg} \mathrm{C} \mathrm{ha}^{-1} 3-\mathrm{bln}^{-1}\right)$ setiap tiga bulan pada praktik agroforesty taungya, pekarangan dan kebun campur

\begin{tabular}{|c|c|c|c|c|c|c|c|}
\hline \multirow{2}{*}{$\begin{array}{l}\text { Praktik } \\
\text { Agroforestry }\end{array}$} & \multirow[b]{2}{*}{ Tingkatan } & \multicolumn{4}{|c|}{ Fluktuasi serapan karbon $\left(\mathrm{kg} \mathrm{C}^{-1} \mathrm{ha}^{-1} \mathrm{bln}^{-1}\right)$} & \multirow{2}{*}{$\begin{array}{l}\text { Total } \\
(\mathrm{kg} \mathrm{C} \text { ha- } \\
\left.{ }^{1} \mathrm{th}^{-1}\right)\end{array}$} & \multirow[t]{2}{*}{$\%$} \\
\hline & & April-Juni & Juli-Sept. & Okt-Des & Jan-Maret & & \\
\hline \multirow{4}{*}{ Kebun campur } & Sapihan & 1.00 & 0.70 & 0.30 & 1.00 & 3.00 & 1.03 \\
\hline & Tiang & 20.70 & 20.32 & 21.00 & 41.63 & 103.65 & 35.72 \\
\hline & Pohon & 28.34 & 11.65 & 65.60 & 77.90 & 183.49 & 63.24 \\
\hline & Total & 50.04 & 32.67 & 86.90 & 120.53 & 290.14 & 100.00 \\
\hline \multirow{4}{*}{ Taungya } & Sapihan & 0.70 & 1.00 & 0.30 & 0.70 & 2.70 & 1.02 \\
\hline & Tiang & 7.50 & 10.60 & 8.40 & 5.40 & 31.90 & 12.03 \\
\hline & Pohon & 60.20 & 70.08 & 40.20 & 60.10 & 230.58 & 86.95 \\
\hline & Total & 68.40 & 81.68 & 48.90 & 66.20 & 265.18 & 100.00 \\
\hline \multirow{4}{*}{ Pekarangan } & Sapihan & 0.16 & 0.09 & 0.18 & 0.13 & 0.56 & 0.24 \\
\hline & Tiang & 0.21 & 1.01 & 1.01 & 0.70 & 2.93 & 1.24 \\
\hline & Pohon & 11.40 & 51.60 & 132.00 & 37.80 & 232.80 & 98.52 \\
\hline & Total & 11.77 & 52.70 & 133.19 & 38.63 & 236.29 & 100.00 \\
\hline
\end{tabular}

\section{Fluktuasi Serapan Karbon Musiman di Praktik Agroforestry}

Berdasarkan Tabel 1 diketahui bahwa serapan karbon di lahan kebun campur, taungya, dan lahan pekarangan yang dihitung setiap 3 bulan dalam satu tahun menunjukan jumlah yang berbeda-beda. Serapan karbon di lahan kebun campur sebesar 32,67-120,53 di lahan taungya sebesar 48,90-81,68 dan di lahan pekarangan sebesar 11,77-133,19 $\mathrm{kg} \mathrm{C} \mathrm{ha}^{-1} 3-\mathrm{bln}^{-1}$. Fluktuasi serapan terbesar di lahan kebun campur terjadi pada periode Januari-Maret, sedangkan serapan terkecil terjadi pada periode Juli-September. Sebaliknya serapan karbon pada tingkat pohon, tiang, dan sapihan di lahan taungya terjadi pada bulan Juli-September, sedangkan serapan karbon terendah terjadi pada periode Oktober-Desember. Fluktuasi serapan karbon di lahan pekarangan tertinggi pada periode Oktober-Desember, sedangkan serapan terendah terjadi pada periode April-Juni. Dinamika serapan karbon di lahan praktik agroforestry sangat dipengaruhi oleh beberapa faktor diantaranya adalah kondisi lingkungan, curah hujan, kandungan air tanah, dan musim (Saha dan Pramod, 2012; Chen, et al., 2016).

Serapan karbon pada tingkat pohon, tiang dan sapihan di kebun campur terjadi pada periode Januari-Maret yaitu masing-masing sebesar 77,90; 41,63 dan 1,00 kg C ha-1 3-bln-1, sebaliknya serapan karbon pohon dan tiang terkecil terjadi pada periode Juli-September masing-masing sebesar 11,65 dan 20,32 $\mathrm{kg} \mathrm{C} \mathrm{ha}^{-1} 3-\mathrm{bln}^{-1}$. Demikian pula serapan karbon tertinggi tingkat pohon, tiang dan sapihan di lahan pekarangan terjadi pada periode OktoberDesember masing-masing sebesar 132,00; 1,01 dan 0,18 kg C ha-1 3-bln-1. Adapun serapan karbon tertinggi tingkat pohon, tiang dan sapihan di lahan taungya terjadi pada periode Juli- 
September berturut-turut sebesar 70,08; 10,60 dan 1,00 $\mathrm{kg} \mathrm{C} \mathrm{ha}^{-1} 3-\mathrm{bln}^{-1}$. Periode pengukuran April-Juni, dan Juli-September mempresentasikan musim kemarau, dan periode OktoberDesember dan Januari-Maret mempresentasikan musim penghujan menunjukkan serapan karbon yang berbeda. Penelitian ini berkesesuain dengan penelitian yang dilakukan oleh Chen et al.,(2016) bahwa pohon Fraxinus griffithii pada bulan Mei-September mempunyai tingkat assimilasi $\mathrm{CO}_{2}$ lebih tinggi dibandingkan pada bulan-bulan yang lain. Lebih lanjut disebutkan bahwa pada periode Mei-September di Taiwan banyak terjadi typoon yang berdampak meningkatkan curah hujan sampai mencapai $3144,5 \mathrm{~mm} \mathrm{th}^{-1}$.

Jenis penyerta pohon G.versteegii menunjukkan penciri penting dalam penetapan praktik agroforestry, dan menentukan besarnya serapan karbon. Pohon penyerta pada praktik agroforestry kebun campur mempunyai jenis yang lebih banyak, sehingga komunitas kebun campur dapat menyerap karbon lebih besar yaitu 290,14 $\mathrm{kg} \mathrm{C} \mathrm{ha}^{-1} \mathrm{th}^{-1}$ dibandingkan dengan praktik agroforestry lainnya (Tabel 2). Hasil penelitian ini sesuai dengan penelitian yang dilakukan oleh Saha dan Pramod (2012) bahwa penanaman pohon P.juliflora, L.leucocephala, A. nilotica dan A.indica sangat baik untuk restorasi dan rehabilitasi lahan yang tergradasi dalam zona riparian, dan dapat meningkatkan serapan karbon.

Tabel 2 menunjukkan bahwa serapan karbon G.versteegii pada berbagai praktik agroforestry besarnya berbeda-beda. Serapan karbon G.versteegii tertinggi tingkat pohon terdapat di lahan taungya yaitu sebesar 230,00 $\mathrm{kg} \mathrm{C} \mathrm{ha}^{-1} \mathrm{th}^{-1}$, kemudian disusul di lahan pekarangan sebesar 20,00 $\mathrm{kg} \mathrm{ha}^{-1} \mathrm{th}^{-1}$, dan lahan kebun campur sebesar 4,9 $\mathrm{kg} \mathrm{ha}^{-1} \mathrm{th}^{-1}$. Saha dan Pramod (2012) menyatakan bahwa pohon mempunyai peranan yang sangat penting dalam penyerapan karbon yaitu melalui peningkatan biomasa per satuan luas dan jumlah pohon dalam komunitas. Jumlah serapan karbon pohon G.versteegii di lahan taungya lebih tinggi disebabkan karena jumlah individu tingkat pohon di lahan taunya jumlahnya lebih banyak dibandingkan dengan di lahan pekarangan dan kebun campur, hal ini diduga berkaitan ketersediaan air yang cukup memadai (melalui irigasi teratur) untuk mendukung proses fotosintesis.

Adapun untuk tingkat tiang serapan G.versteegii paling besar terjadi di lahan kebun campur yaitu sebesar $100,00 \mathrm{~kg} \mathrm{C} \mathrm{ha}^{-1} \mathrm{th}^{-1}$, kemudian disusul di lahan taungya 30,00 $\mathrm{kg} \mathrm{ha}^{-1}$ $\mathrm{th}^{-1}$, dan di lahan pekarangan $2,90 \mathrm{~kg} \mathrm{ha}^{-1} \mathrm{th}^{-1}$. Serapan karbon tingkat tiang di kebun campur mempunyai besaran paling tinggi hal ini disebabkan kartan jumlah pohon G.versteegii tingkat tiang di kebun campur cukup banyak. Banyaknya pohon G.versteegii tingkat tiang di kebun campur diduga karena terjadinya persaingan dengan tanaman penyerta yang mempunyai tajuk yang berat seperti T. grandis, M. zapota, E.aquea, D.longan dan lainnya. Disamping itu diduga keterbatasan persediaan air di musim kemarau menjadi faktor dominan dalam pertumbuhan 
diameter. Lorenz dan La1 (2010) menyatakan bahwa air merupakan faktor yang sangat diperlukan oleh pohon untuk memproduksi biomasa dan penyerapan karbon melalui proses fotosintesis. Serapan karbon tingkat sapihan jenis G.versteegii maupun jenis lain di ketiga praktik agroforestry jumlahnya cukup sedikit, hal ini sesuai dengan jumlah biomasa yang dihasilkan.

Tabel 2. Serapan karbon jenis-jenis yang ditanam di lahan taungya, pekarangan dan kebun campur setiap tiga bulan selama satu tahun.

\begin{tabular}{|c|c|c|c|c|c|c|c|c|}
\hline \multirow[t]{2}{*}{$\begin{array}{c}\text { Praktik } \\
\text { Agroforestry }\end{array}$} & \multirow[t]{2}{*}{ Tingkat } & \multirow[t]{2}{*}{ Jenis } & \multicolumn{4}{|c|}{$\begin{array}{c}\text { Fluktuasi serapan karbon (kg C } \\
\left.\text { ha }^{-1} 3-b^{-1}\right)\end{array}$} & \multirow{2}{*}{$\begin{array}{c}\text { Total } \\
\left(\mathrm{kg} \mathrm{C} \mathrm{ha}^{-}\right. \\
\left.{ }^{\mathbf{1}} \text { th }^{-1}\right) \\
\end{array}$} & \multirow[t]{2}{*}{$\%$} \\
\hline & & & $\begin{array}{l}\text { Apr- } \\
\text { Juni }\end{array}$ & $\begin{array}{c}\text { Jul- } \\
\text { Sept }\end{array}$ & $\begin{array}{l}\text { Okt- } \\
\text { Des }\end{array}$ & $\begin{array}{c}\text { Jan- } \\
\text { Maret }\end{array}$ & & \\
\hline \multirow{22}{*}{ Kebun campur } & Sapihan & Gyrinops versteegii & 1.00 & 0.70 & 0.30 & 1.00 & 3.00 & 1.03 \\
\hline & Tiang & Gliricidea sepium & 0.10 & 0.02 & 0.30 & 0.30 & 0.72 & 0.25 \\
\hline & & Tectona grandis & 0.00 & 0.00 & 0.10 & 0.50 & 0.60 & 0.21 \\
\hline & & Leucaena leuchocephala & 0.30 & 0.20 & 0.30 & 0.40 & 1.20 & 0.41 \\
\hline & & Bauhinia purpurea & 0.00 & 0.00 & 0.00 & 0.03 & 0.03 & 0.01 \\
\hline & & Mangifera indica & 0.30 & 0.10 & 0.30 & 0.40 & 1.10 & 0.38 \\
\hline & & Gyrinops versteegii & 20.00 & 20.00 & 20.00 & 40.00 & 100.00 & 34.47 \\
\hline & Pohon & Tectona grandis & 6.00 & 2.00 & 20.00 & 20.00 & 48.00 & 16.54 \\
\hline & & Paraserianthes falcataria & 7.00 & 2.00 & 10.00 & 10.00 & 29.00 & 10.00 \\
\hline & & Manilkara zapota & 8.00 & 4.00 & 10.00 & 10.00 & 32.00 & 11.03 \\
\hline & & Leucaena glauca & 0.10 & 0.05 & 0.30 & 0.10 & 0.55 & 0.19 \\
\hline & & Gyrinops versteegii & 0.90 & 2.00 & 1.00 & 1.00 & 4.90 & 1.69 \\
\hline & & Dimocarpus longan & 0.30 & 0.03 & 7.00 & 5.00 & 12.33 & 4.25 \\
\hline & & Eugenia aquea & 3.00 & 0.30 & 3.00 & 5.00 & 11.30 & 3.89 \\
\hline & & Aleurites moluccana & 0.07 & 0.04 & 0.60 & 0.10 & 0.81 & 0.28 \\
\hline & & Mangifera indica & 0.10 & 0.03 & 0.30 & 0.40 & 0.83 & 0.29 \\
\hline & & Leucaena leuchocephala & 2.00 & 0.30 & 7.00 & 20.00 & 29.30 & 10.10 \\
\hline & & Artocarpus heterophyllus & 0.10 & 0.00 & 0.20 & 0.20 & 0.50 & 0.17 \\
\hline & & Eugenia malaccensis & 0.00 & 0.00 & 4.00 & 2.00 & 6.00 & 2.07 \\
\hline & & Cassia siamea & 0.07 & 0.00 & 0.20 & 0.10 & 0.37 & 0.13 \\
\hline & & Gliricidea sepium & 0.70 & 0.90 & 2.00 & 4.00 & 7.60 & 2.62 \\
\hline & & Total & 50.04 & 32.67 & 86.90 & 120.53 & 290.14 & 100.00 \\
\hline \multirow{6}{*}{ Taungya } & Sapihan & Gyrinops versteegii & 0.70 & 1.00 & 0.30 & 0.70 & 2.70 & 1.02 \\
\hline & Tiang & Tectona grandis & 0.50 & 0.60 & 0.40 & 0.40 & 1.90 & 0.72 \\
\hline & & Gyrinops versteegii & 7.00 & 10.00 & 8.00 & 5.00 & 30.00 & 11.31 \\
\hline & Pohon & Sweitenia macrophylla & 0.20 & 0.08 & 0.20 & 0.10 & 0.58 & 0.22 \\
\hline & & Gyrinops versteegii & 60.00 & 70.00 & 40.00 & 60.00 & 230.00 & 86.73 \\
\hline & & Total & 68.40 & 81.68 & 48.90 & 66.20 & 265.18 & 100.00 \\
\hline \multirow[t]{6}{*}{ Pekarangan } & Sapihan & Sweitenia macrophylla & 0.09 & 0.03 & 0.10 & 0.05 & 0.27 & 0.11 \\
\hline & & Eugenia aquea & 0.02 & 0.02 & 0.02 & 0.01 & 0.07 & 0.03 \\
\hline & & Gyrinops versteegii & 0.05 & 0.04 & 0.06 & 0.07 & 0.22 & 0.09 \\
\hline & Tiang & Sweitenia macrophylla & 0.01 & 0.01 & 0.01 & 0.00 & 0.03 & 0.01 \\
\hline & & Gyrinops versteegii & 0.20 & 1.00 & 1.00 & 0.70 & 2.90 & 1.23 \\
\hline & Pohon & Gyrinops versteegii & 4.00 & 9.00 & 4.00 & 3.00 & 20.00 & 8.46 \\
\hline
\end{tabular}




\begin{tabular}{|c|c|c|c|c|c|c|c|c|}
\hline \multirow[t]{2}{*}{$\begin{array}{c}\text { Praktik } \\
\text { Agroforestry }\end{array}$} & \multirow[t]{2}{*}{ Tingkat } & \multirow[t]{2}{*}{ Jenis } & \multicolumn{4}{|c|}{$\begin{array}{c}\begin{array}{c}\text { Fluktuasi serapan karbon (kg C } \\
\left.\text { ha }^{-1} 3-b^{-1}\right)\end{array} \\
\end{array}$} & \multirow{2}{*}{$\begin{array}{c}\text { Total } \\
\text { (kg C ha- } \\
\left.{ }^{1} \text { th }^{-1}\right)\end{array}$} & \multirow[t]{2}{*}{$\%$} \\
\hline & & & $\begin{array}{l}\text { Apr- } \\
\text { Juni }\end{array}$ & $\begin{array}{l}\text { Jul- } \\
\text { Sept }\end{array}$ & $\begin{array}{l}\text { Okt- } \\
\text { Des }\end{array}$ & $\begin{array}{c}\text { Jan- } \\
\text { Maret }\end{array}$ & & \\
\hline & & Sweitenia macrophylla & 6.00 & 20.00 & 10.00 & 20.00 & 56.00 & 23.70 \\
\hline & & Cocos nucifera & 0.10 & 2.00 & 0.30 & 0.10 & 2.50 & 1.06 \\
\hline & & Mimusops elengi & 0.00 & 9.00 & 5.00 & 5.00 & 19.00 & 8.04 \\
\hline & & Lansium domesticum & 0.60 & 1.00 & 0.70 & 0.70 & 3.00 & 1.27 \\
\hline & & Tectona grandis & 0.00 & 0.60 & 2.00 & 4.00 & 6.60 & 2.79 \\
\hline & & Spondias dulcis & 0.70 & 10.00 & 110.00 & 5.00 & 125.70 & 53.20 \\
\hline & & Total & 11.77 & 52.70 & 133.19 & 38.63 & 236.29 & 100.00 \\
\hline
\end{tabular}

\section{Pengaruh Faktor Lingkungan terhadap Serapan Karbon}

Sistem agroforestri dipercaya mempunyai potensi yang tinggi untuk menyerap $\mathrm{C}$ dalam bentuk gas $\mathrm{CO}_{2}$ dari atmosfer dikarenakan dapat mengoptimalkan kondisi tapak (mencakup tanah, intensitas cahaya, nutrisi, dan air) untuk pertumbuhan, dibandingkan dengan sistem pertanian maupun peternakan (Nair et al., 2010). Serapan karbon dalam sistem agroforestry sangat dipengaruhi oleh jenis tanaman yang diusahakan, umur tanaman, manajemen termasuk praktik agroforestry yang dipilih. Berdasarkan studi terhadap berbagai pola agroforestry dalam berbagai kondisi ekologis menunjukkan bahwa sistem pertanian yang berbasis kayu dengan sistem pertanian yang tidak berbasis kayu, serapan karbon terbesar berada pada permukaan tanah yang berdekatan dengan pohon, dibandingkan dengan yang jauh dari pohon.

Serapan karbon di atas tanah di lahan kebun campur Sragen paling tinggi terjadi pada bulan Januari-Maret, sedangkan serapan karbon paling rendah terjadi pada bulan JuliSeptember tahun 2017 (Gambar 2). Periode bulan Juli-September merupakan bulan dengan hari hujan dan curah hujan paling rendah (puncak musim kemarau). Adapun bulan JanuariMaret mempunyai hari hujan dan curah hujan yang paling tinggi (puncak musim penghujan). Tanaman pada lahan kebun campur mencapai serapan karbon paling tinggi di bulan JanuariMaret, diduga berkaitan dengan ketersedian air yang mencukupi. Menurut Lorenz \& La1 (2010) menyatakan bahwa $\mathrm{H}_{2} \mathrm{O}$ merupakan senyawa utama yang diperlukan untuk proses photosynthesis, yang merupakan proses masuknya karbon ke komunitas agroforestry. Senyawa $\mathrm{H}_{2} \mathrm{O}$ diperlukan untuk proses photosynthesis, di lain pihak senyawa $\mathrm{H}_{2} \mathrm{O}$ juga dihasilkan dari proses respirasi. 


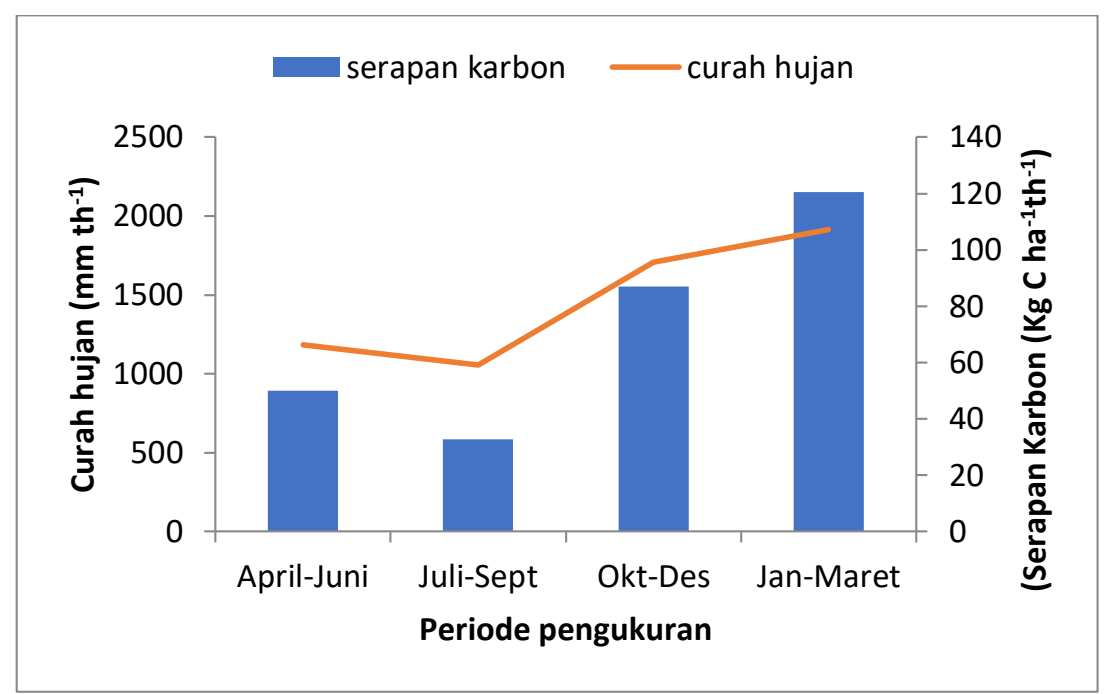

Gambar 2. Grafik curah hujan dan serapan karbon di atas tanah di lahan kebun campur, kabupaten Sragen tahun 2017 (BPS, 2017).

Pohon G.versteegii di lahan taungya mempunyai serapan karbon tertinggi terjadi pada bulan Juli-September, sedangkan serapan karbon terendah pada bulan Oktober-Desember (Gambar 3). Serapan karbon tertinggi pada bulan Juli-September diduga karena ketersediaan air, nurtisi dan sinar matahari pada bulan itu tersedia optimal untuk melakukan proses assimilasi karbon. Air $\left(\mathrm{H}_{2} \mathrm{O}\right)$ tersedia di tapak dalam jumlah yang cukup karena berasal dari irigasi teknis. Sebaliknya serapan karbon pada bulan Oktober-Desember paling rendah hal ini diduga di tapak terjadi genangan air (waterlogging), karena tapak berada di tengah lahan persawahan dengan air tanah dangkal. Akhtar dan Nazir (2013) menyatakan bahwa dampak negative waterlogging adalah berkurangnya konsentrasi oksigen di dalam tanah, terakumulasinya ethylene, serta terganggunya penyerapan nutrisi dari dalam tanah. Waterlogging menyebabkan kondisi hypoxia (rendahnya konsentrasi oksigen) dalam tanah, dikarenakan tingkat kelarutan oksigen dalam air rendah.

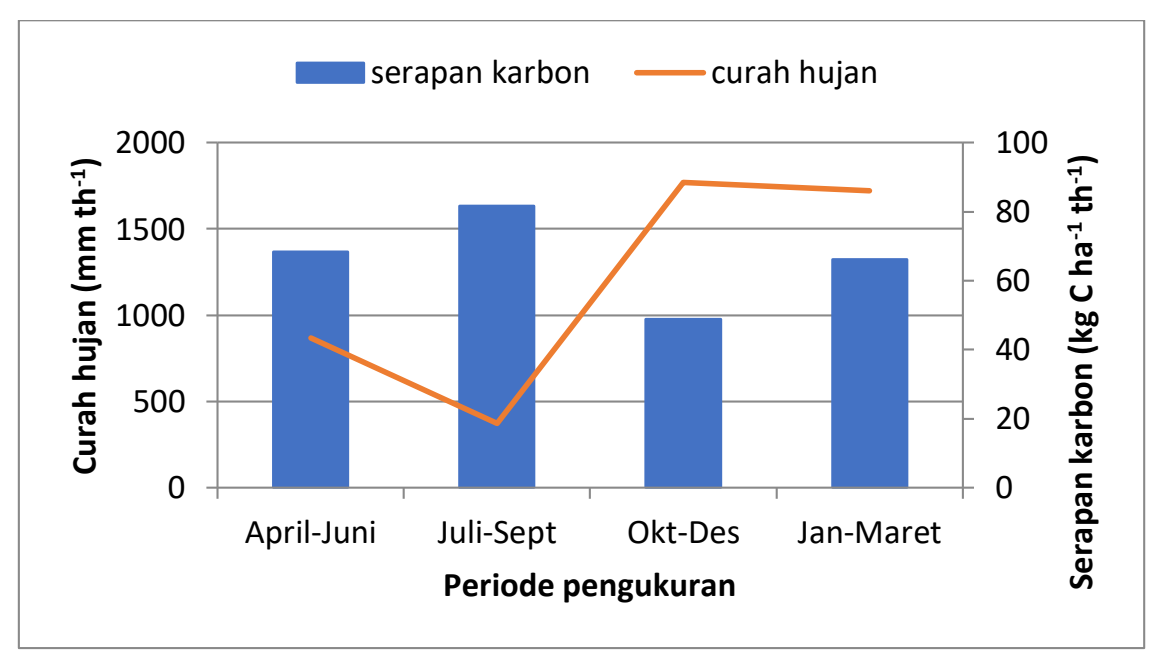

Gambar 3. Grafik curah hujan dan serapan karbon di atas tanah di lahan taungya kabupaten Karanganyar tahun 2017 (BPS, , 2017). 
Gambar 4 menunjukkan bahwa bulan April-September tahun 2017 jumlah hari hujan mulai menurun dan mulai naik sampai bulan Oktober artinya bulan April-September merupakan periode musim kemarau, ketersediaan air mencapai titik terbawah, dengan kondisi seperti ini akan menyebabkan pertumbuhan G.versteegii paling rendah dibandingkan dengan bulan yang lain. Pohon G.versteegii yang ditanam di lahan pekarangan di Karanganyar mencapai kenaikan serapan karbon tertinggi pada bulan Oktober-Desember. Kenaikan serapan karbon paling rendah terjadi pada bulan April-Juni, sedangkan kenaikan tertinggi terjadi pada bulan Oktober-Desember. Pertumbuhan G.versteegii di lahan pekarangan tumbuh baik pada musim penghujan, dimana ketersediaan air sangat mencukupi untuk pertumbuhan G.versteegii. Air merupakan nutrisi yang sangat dibutuhkan oleh tanaman untuk pertumbuhan (biomasa) termasuk tanaman G.versteegii. Ketersediaan air yang tidak mencukupi (deficit) akan menyebabkan pertumbuhan tanaman terganggu (Spurr dan Barnes, 1980).

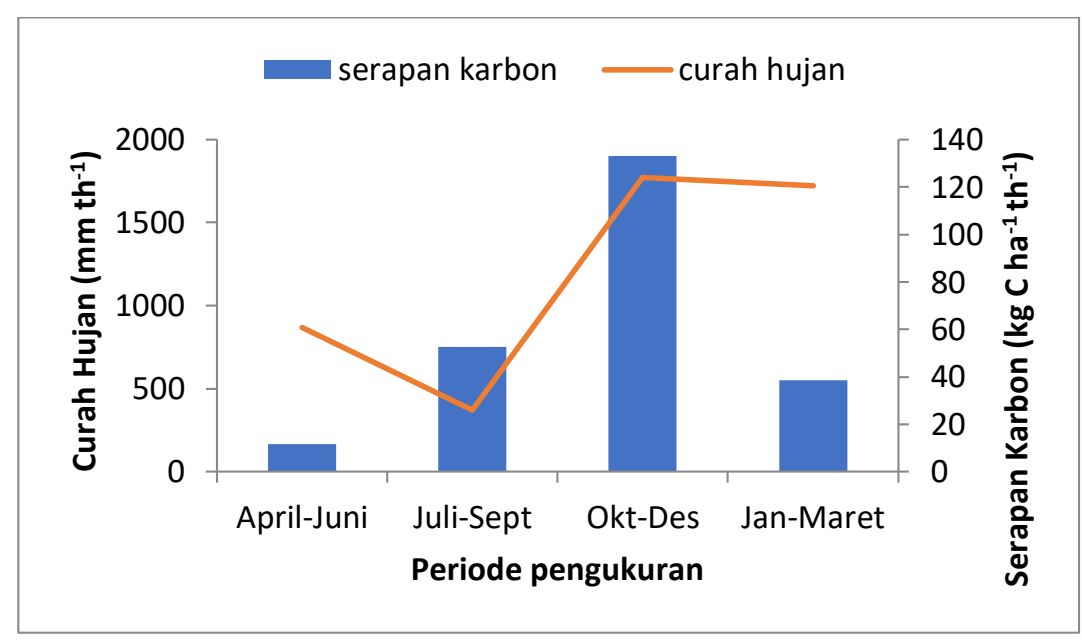

Gambar 4. Grafik curah hujan dan serapan karbon di atas tanah di lahan pekarangan kabupaten Karanganyar tahun 2017 (BPS $\left._{\mathrm{b}}, 2017\right)$.

Gambar 5a dan 5c menunjukkan bahwa curah hujan berkorelasi positif dengan serapan karbon di atas tanah di lahan kebun campur dan di lahan pekarangan. Semakin besar curah hujan akan diikuti dengan semakin besar serapan karbonnya. Hubungan curah hujan dan serapan karbon di lahan kebun campur kabupaten Sragen diformulasikan dengan persamaan regresi sederhana yaitu $\mathrm{y}=0,00004 \mathrm{x}+0,0161$, dimana $\mathrm{y}=$ serapan karbon, dan $\mathrm{x}=$ curah hujan, dengan nilai $\mathrm{R}^{2}$ sebesar 0,8470 . Sedangkan hubungan curah hujan dan serapan karbon di pekarangan kabupaten Karanganyar diformulasikan dengan persamaan regresi sederhana yaitu $\mathrm{y}=0,00001 \mathrm{x}+0,0501$, dengn nilai $\mathrm{R}^{2}$ sebesar 0,2434. Curah hujan sangat berkaitan dengan net primary production (NPP) dan gross primary production (GPP). Nair (1993) menyatakan 
bahwa untuk melakukan fiksasi karbon $\left(\mathrm{CO}_{2}\right)$ diperlukan air $\left(\mathrm{H}_{2} \mathrm{O}\right)$ dalam proses fotosintesis. Reaksi fotosintesis dapat ditulis sebagai berikut:

$$
6 \mathrm{CO}_{2}+12 \mathrm{H}_{2} \mathrm{O}+\text { Energi matahari } \rightarrow \mathrm{C}_{6} \mathrm{H}_{12} \mathrm{O}_{6}+6 \mathrm{H}_{2} \mathrm{O}+6 \mathrm{O}_{2}
$$

Karbon dalam bentuk gas $\mathrm{CO}_{2}$ diserap dari atmosfer, sedangkan $\mathrm{H}_{2} \mathrm{O}$ diambil dari dalam tanah. Air $\left(\mathrm{H}_{2} \mathrm{O}\right)$ merupakan satu substrat yang sangat penting dalam proses fotosintesis yaitu proses fiksasi $\mathrm{CO}_{2}$ untuk diserap dan disimpan di tempat penyimpanan yang lebih aman (dalam tanaman). Tingkat fotosintesis sangat tergantung kepekaan stomata, dimana kepekaan stomata ini sangat dipengaruhi oleh ketersediaan air dan konsentrasi $\mathrm{CO}_{2}$ di daun. Efisiensi fotosistensis ditentukan oleh ketersedian air, nutrisi, dan cahaya matahari (Lorenz \& La1, 2010; Nair et al., 2010). Proses partisi karbon menjadi daun, kulit, cabang, batang, akar dan organorgan reproduktif dapat berjalan karena ketersediaan $\mathrm{H}_{2} \mathrm{O}$ yang tercukupi, disamping ketersediaan unsur hara dan sinar matahari.

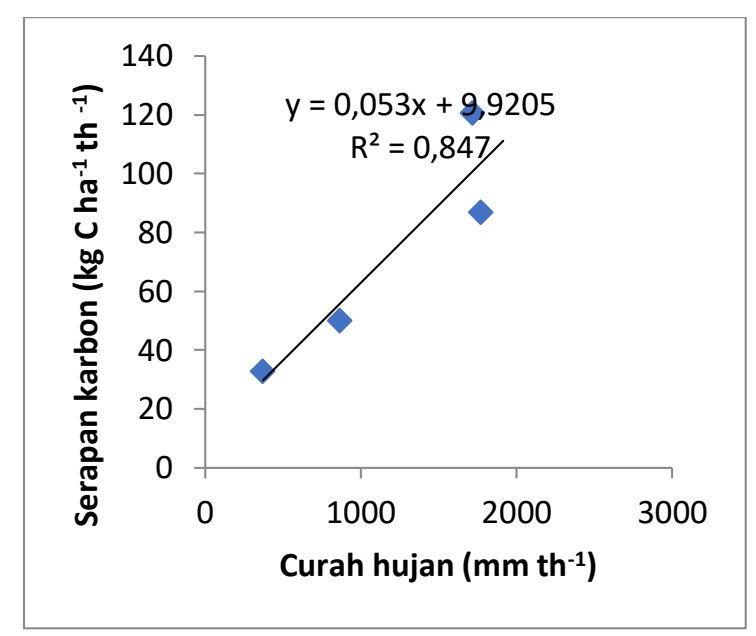

(a)

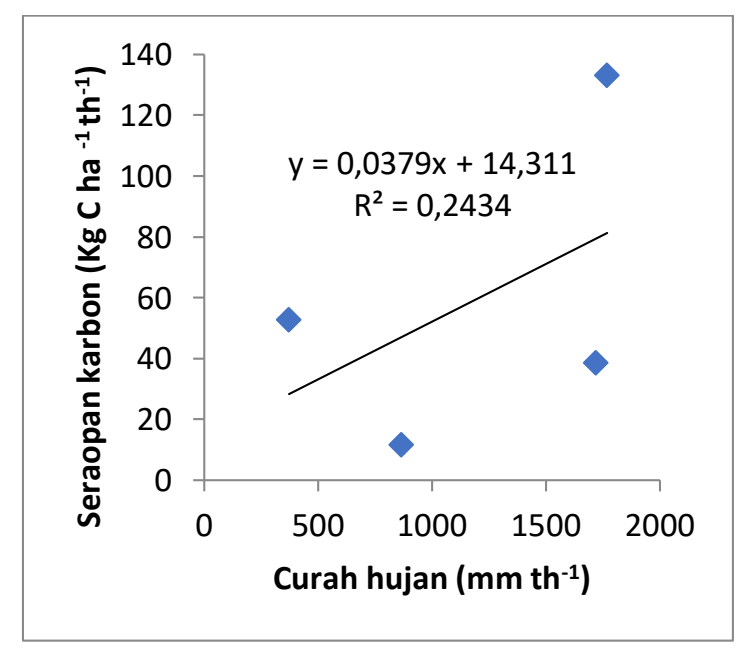

(c)

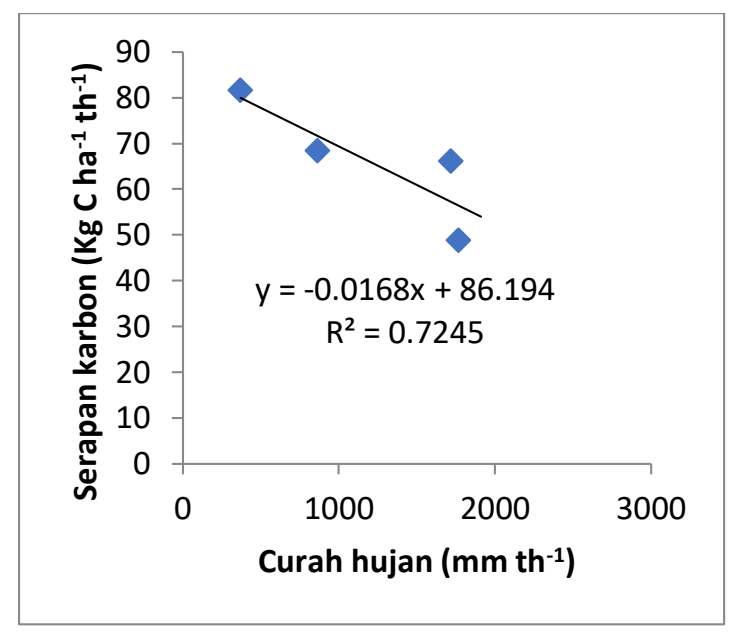

(b)

Gambar 5. Kecenderungan curah hujan terhadap serapan karbon di (a) kebun campur (b) lahan taungya, dan (c) lahan pekarangan. 
Gambar 5b menunjukkan bahwa curah hujan berkorelasi negatif terhadap serapan karbon di atas tanah di lahan taungya, artinya semakin tinggi curah hujan akan diikuti dengan jumlah serapan karbon semakin sedikit. Besarnya hubungan curah hujan dan serapan karbon di lahan taungya diformulasikan dengan persamaan regresi sederhana $y=-0,0168 x+86,194$, dimana $\mathrm{y}=$ serapan karbon dan $\mathrm{x}=$ curah hujan, dengan nilai $\mathrm{R}^{2}$ sebesar 0,7245 . Korelasi negatif antara jumlah serapan karbon dengan curah hujan di lahan taungya, diduga disebabkan adanya pengaruh waterlogging yang menyebabkan terjadinya hypoxia di lapisan perakaran. Kondisi hypoxia ini akan mengganggu respirasi perakaran dan berdampak pada terganggunya serapan karbon.

\section{KESIMPULAN}

1. Serapan karbon di atas tanah paling tinggi terdapat di lahan kebun campur yaitu sebesar $290,14 \mathrm{~kg} \mathrm{C} \mathrm{ha}^{-1} \mathrm{th}^{-1}$, kemudian disusul di lahan taungya sebesar $265,18 \mathrm{~kg} \mathrm{C} \mathrm{ha}^{-1} \mathrm{th}^{-1}$, dan di lahan pekarangan sebesar 236,29 $\mathrm{kg} \mathrm{C} \mathrm{ha}^{-1} \mathrm{th}^{-1}$. Persentase serapan karbon tingkat pohon di tiga praktik agroforestry sebesar 63,24-98,52\%, tingkat tiang sebesar 1,24-35,72\%, dan tingkat sapihan sebesar 0,24-1,03\%.

2. Fluktuasi serapan karbon tertinggi di lahan kebun campur dan pekarangan terjadi pada musim penghujan yaitu Januari-Maret (120,53 $\left.\mathrm{kg} \mathrm{C} \mathrm{ha}^{-1} 3-\mathrm{bln}^{-1}\right)$ dan Oktober-Desember $\left(133,19 \mathrm{~kg} \mathrm{C} \mathrm{ha}^{-1} 3-\mathrm{bln}^{-1}\right)$. Sebaliknya fluktuasi serapan karbon tertinggi di lahan taungya justru terjadi pada musim kemarau yaitu Juli-September (81,68 $\mathrm{kg} \mathrm{C} \mathrm{ha}^{-1} 3$-bln ${ }^{-1}$ ), kondisi ini diduga dikarenakan dampak waterlogging yang menyebabkan terganggunya proses asimilasi karbon.

\section{UCAPAN TERIMA KASIH}

Penulis mengucapkan terima kasih kepada Kementerian Riset, Teknologi dan Pendidikan Tinggi yang telah memberikan bantuan penelitian melalui kontrak penelitian nomor: 2433/UNI.P.III/DITLIT/LT/2017. Diucapkan terima kasih juga kepada Dinas Kehutanan dan Perkebunan Kabupaten Sragen dan Ir. Wawan yang telah memberikan izin lokasi penelitian.

\section{DAFTAR PUSTAKA}

Agonafir H.,\& M. Worku . 2017. Carbon Stock in Gullele Botanical Garden: Implications for Carbon Emission Reduction, North Western Addis Ababa Ethiopia. Journal of Environment and Earth Science. ISSN 2224-3216(paper) ISSN2225-0948 (online). Vol.7, no.2 pp 40-51. 
Akhtar I dan Nazir, N. 2013. Effect of Waterlogging and Drought Stress in Plants. International journal of water reaources and environment sciences 2(2):34-40. ISSN XXXXXXXX DOI:10.5829/idos.ijwres.2013.2.2.11125 @ IDOSI Publication.

Albrechi A. \& S.T. Kandji. 2003. Carbon Sequestration in Tropical Agroforesry Sistem. Journal of Agriculture Ecosistem and Environment. 99 (2003) 15-27. Elsevier. http://www.elsevier.com/locate/agee. Available on line at www.sciencedirect.com.kur

Anonimous. 2013. Pedoman Penggunaan Model Alometrik untuk Pendugaan Biomassa dan Stok Karbon Hutan di Indonesia. Peraturan Kepala Badan Penelitian dan Pengembangan Kehutanan Nomor:P.01/VIII-P3KR/2012. Kementerian Kehutanan Badan Penelitian dan Pengembangan Kehutanan Pusat Penelitian dan Pengembangan Konservasi dan Rehabilitasi. Indonesia.

Arora G., S. Chaturvendi , R. Kaushal , A. Nain, S. Tewari, N.M.Alam, \& O.P. Chaturvendi. 2014. Growth, Biomass, Carbon Stocks, and Sequestration in An Age Series of Populus deltoids Plantation in Tarai Region of Central Himalaya. Turkish Journal of Agriculture and Forestry (2014) 38:550-560. DOI:10.3906/tar-130794.http:www.journal.tubitak.gov.tr/agriculture/.

Badan Pusat Statistik/BPS a. 2017. Kecamatan Karanganyar Dalam Angka 2017. Karanganyar: (C) BPS Kabupaten Karanganyar.

BPS $_{b} /$ Badan Pusat Statistik . 2017. Kabupaten Sragen Dalam Angka 2017. BPS Kabupaten Sragen, Jawa Tengah

Chave J, C. Andalo, S. Brown, M.A. Cains, J.Q.Chambers, D.Eamus, H. Folster, F. Fromard, N.Higuchi, T.Kira, J.P. Lescure, B.W. Nelson, H. Ogawa, H.Puig, B.Riera, T. Yamakura. 2005. Tree Allometry and Improved Estimation of Carbon Stocks and Balance in Tropical Forest. Oecology (2005) 145:87-99. DOI 10.1007/s00442005-0100-x. Springer-Verlag.

Chen C.Y. Wang, and J.Yu, 2016. Three-Year Study on Diurnal and Seasonal CO2 Sequestration of a Young Fraxinus griffithii Plantation in Southern Taiwan. Forest Journal 2016,7,230. MDPI. Doi:10.3390/f7100230.

Gupta RK, V. Kumar, K.R. Sharma, T.S. Buttar, G.Singh, \& G. Mir. 2017. Carbon Sequestration Potential through Agroforestry: A Review. International Journal of Current Microbiology and AppliedScience ISSN: 2319-7706 Volume 6 Number 8 (2017) pp.211-220.http://www.ijcmas.com.

Hairiah K, S. Dewi, F. Agus, S. Velarde, A. Ekadinata, S. Rahayu \& M. van Noordwijk. 2010. Measuring Carbon Stocks Across Land Use System: A Manual. Bogor, Indonesia.World Agroforestry Centre (ICRAF), SEA Regional Office, 155 pages.

Hani, A., Y. Indrajaya, P. Suryato, \& Budiadi. 2016. Dryland Agroforestry Practices in Menoreh Hill, Kulon Progo. AGRIVITA Journal of Agricultural Science. 38(2): 193-203. Doi: 10.17503/agrivita.v38i2.416.

Istomo dan Farida, N.E., 2017. Potensi Simpanan Karbon di Atas Permukaan Tanah Tegakan Acacia nilotica L. (willd) ex.Del. di Taman Nasional Baluran, Jawa Timur. Jurnal Pengelolaan Sumberdaya Alam dan Lingkungan Vol.7 No.2 (Agustus 2017): 155 162

Kumar, B.M., \& P.K.R. Nair. 2011. Carbon Sequestration Potential of Agroforestry Systems Opportunities and Challenges. The United State of America. Springer.

Labata MM, C. Edgardo, Aranico, A. Catalina, J. Hermis , \& R.F. Amparado. 2012. Carbon Stock Assessment of Three Selected Agroforestry Sistem in Bukidnon, Philippines. Advances in Environmental Science International Journal of theBioflux Society. Open Access Research article. http://www.aes.bioflux.com.ro/. 
Lorenz K. dan R. La1. 2010. Carbon Sequestration in Forest Ecosystem. ISBN 978-90-4813265-2. E-ISBN 978-90-481-3266-9. DOI 10.1007/978-90-481-3266-9. Springer Dordrecht Heideberg London New York.

Mulyaningsih, T. And I. Yamada. 2007. Notes on Some Species of Agarwood In Nusa Tenggara, Celebes and West Papua. Sulawesi.cseas.kyoto-u.ac.jp/final_ reports2007/article/43-tri.pdf. diunduh 25 April 2016.

Nair, PKR.1993. An Introduction to Agroforestry. Kluwer Academic Publisher. Dordrecht, the Netherlands.

Nair, PKR, VD. Nair, M. Kumar, dan JM.Showalter.2010. Carbon Sequestration in Agroforestry System. Advance in Agronomy. Volume 108. ISSN 0065-2113 DOI:10.1016/s0065-2113(10)08005-3 Elsevier Inc.

Natalia D, E. Arisoesiloningsih, \& K. Hairiah. 2017. Are High Carbon Stocks in Agroforestry and Forest Associated with High Plant Species Diversity? AGRIVITA Journal of Agricultural Science. 39 (1):74-82. Accredited SK No.81/DIKTI/Kep/2011. Permalink/DOI:http://dx.doi.org/10.17503/agrivita.v39i1.676.

Noor'an RF., Jaya INS., Puspaningsih, N. 2015. Pendugaan Perubahan Stok Karbon di Taman Nasional Bromo Tengger Semeru. Media Konservasi Vol 20.No.2Agustus 2015:177-186

Peichl, M., V. Naresh, Thevathasan, M. Andrew, Gordon, J. Huss \& R.A. Abohassan. 2006. Carbon Sequestration Potentials in Temperate Tree-Based Intercropping Systems, Southern Ontario, Canada. Journal of Agroforestry Sistems (2006) 66:243257. DOI 10.1007/s10457-005-0361-8

Purwanto, R., Rohman, Maryudi, A., Yuwono, T., Permadi, D.B, dan Sanjaya, M. 2012. Potensi Biomassa dan Simpanan Karbon Jenis-jenis Tanaman Berkayu di Hutan Rakyat Desa Nglanggeran, Gunung Kidul, Daerah Istimewa Yogyakarta. Jurnal Ilmu Kehutanan VOl VI No.2 Juli-September 2012.ISSN:0126-4451. Fakultas Kehutanan UGM. Yogyakarta.

Saha, R. \& J.H.A.Pramod. 2012. Carbon Sequestration Potentials of Agroforestry Systems under Climate Change Scenario- Brief Review with special Emphasis on NorthEastern Hill Regions. Journal of Agricultural Physics. Vol. 12 No. 2 pp. 100-106. ISSN 0973-032X http://www.agrophysics.in

Standar Nasional Indonesia. 2011. Pengukuran dan Penghitungan Cadangan Karbon Pengukuran Lapangan untuk Penaksiran Cadangan Karbon Hutan (ground-based forest carbon accounting). SNI 7724:2011. Badan Standarisasi Nasional.Indonesia.

Soto-Pinto L, M. Anzueto, J. Mendoza, G.Jimenez, \& B.D.Jong. 2010. Carbon Sequestration through Agroforestry in Indigenous Communities of Chiapas, Mexico. Agroforest Sistem Journal (2010) 78:39-51.DOI 10.1007/s10457-009-9247-5. Springer.

Spurr, S.H, and Barnes, B.V. 1980. Forest Ecology. Third edition. John Wiley and Sons. New York 